\title{
Global effect of COVID-19 pandemic on physical activity, sedentary behaviour and sleep among 3- to 5-year-old children: a longitudinal study of 14 countries
}

Anthony D. Okely ${ }^{1 *}$, Katharina E. Kariippanon ${ }^{1}$, Hongyan Guan², Ellie K. Taylor ${ }^{3}$, Thomas Suesse ${ }^{4}$, Penny L. Cross ${ }^{3}$, Kar Hau Chong ${ }^{3}$, Adang Suherman ${ }^{5}$, Ali Turab ${ }^{6}$, Amanda E. Staiano ${ }^{7}$, Amy S. Ha ${ }^{8}$, Asmaa El Hamdouchi ${ }^{9}$, Aqsa Baig ${ }^{6}$, Bee Koon Poh ${ }^{10}$, Borja Del Pozo-Cruz ${ }^{11}$, Cecilia H. S. Chan ${ }^{8}$, Christine Delisle Nyström ${ }^{12}$, Denise Koh ${ }^{13}$, E. Kipling Webster ${ }^{14}$, Himangi Lubree ${ }^{15}$, Hong Kim Tang ${ }^{16}$, Issad Baddou' ${ }^{9}$, Jesus Del Pozo-Cruz ${ }^{17}$, Jyh Eiin Wong ${ }^{10}$, Kuston Sultoni ${ }^{5}$, Maria Nacher ${ }^{3}$, Marie Löf ${ }^{18}$, Mingming Cui ${ }^{2}$, Mohammad Sorowar Hossain ${ }^{19}$, P. W. Prasad Chathurangana ${ }^{20}$, Uddhavi Kand ${ }^{15}$, V. P. Pujitha Wickramasinghe ${ }^{20}$, Rebecca Calleia ${ }^{3}$, Shameema Ferdous ${ }^{19}$, Thanh Van Kim ${ }^{16}$, Xiaojuan Wang ${ }^{2}$ and Catherine E. Draper ${ }^{21}$

\begin{abstract}
Background: The restrictions associated with the 2020 COVID-19 pandemic has resulted in changes to young children's daily routines and habits. The impact on their participation in movement behaviours (physical activity, sedentary screen time and sleep) is unknown. This international longitudinal study compared young children's movement behaviours before and during the COVID-19 pandemic.

Methods: Parents of children aged 3-5 years, from 14 countries (8 low- and middle-income countries, LMICs) completed surveys to assess changes in movement behaviours and how these changes were associated with the COVID-19 pandemic. Surveys were completed in the 12 months up to March 2020 and again between May and June 2020 (at the height of restrictions). Physical activity (PA), sedentary screen time (SST) and sleep were assessed via parent survey. At Time 2, COVID-19 factors including level of restriction, environmental conditions, and parental stress were measured. Compliance with the World Health Organizations (WHO) Global guidelines for PA (180 min/ day [ $\geq 60$ min moderate- vigorous PA]), SST ( $\leq 1 \mathrm{~h} /$ day) and sleep (10-13 h/day) for children under 5 years of age, was determined.
\end{abstract}

Results: Nine hundred- forty-eight parents completed the survey at both time points. Children from LMICs were more likely to meet the PA (Adjusted Odds Ratio [AdjOR] $=2.0,95 \%$ Confidence Interval [CI] 1.0,3.8) and SST $($ AdjOR $=2.2,95 \% \mathrm{Cl} 1.2,3.9)$ guidelines than their high-income country $(\mathrm{HIC})$ counterparts. Children who could go (Continued on next page)

\footnotetext{
* Correspondence: tokely@uow.edu.au

${ }^{1}$ Early Start, School of Health and Society, Faculty of the Arts, Social Science and Humanities, University of Wollongong, Wollongong, NSW 2522, Australia Full list of author information is available at the end of the article
}

(c) The Author(s). 2021 Open Access This article is licensed under a Creative Commons Attribution 4.0 International License, which permits use, sharing, adaptation, distribution and reproduction in any medium or format, as long as you give appropriate credit to the original author(s) and the source, provide a link to the Creative Commons licence, and indicate if changes were made. The images or other third party material in this article are included in the article's Creative Commons licence, unless indicated otherwise in a credit line to the material. If material is not included in the article's Creative Commons licence and your intended use is not permitted by statutory regulation or exceeds the permitted use, you will need to obtain permission directly from the copyright holder. To view a copy of this licence, visit http://creativecommons.org/licenses/by/4.0/ The Creative Commons Public Domain Dedication waiver (http://creativecommons.org/publicdomain/zero/1.0/) applies to the data made available in this article, unless otherwise stated in a credit line to the data. 


\begin{abstract}
(Continued from previous page)
outside during COVID-19 were more likely to meet all WHO Global guidelines (AdjOR $=3.3,95 \% \mathrm{Cl}$ 1.1,9.8) than

those who were not. Children of parents with higher compared to lower stress were less likely to meet all three guidelines ( $\mathrm{AdjOR}=0.5,95 \% \mathrm{Cl}$ 0.3,0.9).

Conclusion: PA and SST levels of children from LMICs have been less impacted by COVID-19 than in HICs. Ensuring children can access an outdoor space, and supporting parents' mental health are important prerequisites for enabling pre-schoolers to practice healthy movement behaviours and meet the Global guidelines.
\end{abstract}

Keywords: 24-h movement behaviours, Low- and middle-income countries, Preschool, Outdoors, Play, Quarantine

\section{Introduction}

With the emergence of the novel Coronavirus Disease (COVID-19) in 2019 and subsequent global pandemic declared by the World Health Organization (WHO) in March 2020, governments implemented strategies to prevent the spread of the virus and protect their citizens. In most nations, physical distancing measures and requirements to remain at home placed unprecedented restrictions on children's ability to be active. While these measures were essential to protect the public's health, some unintended consequences may have resulted from these restrictions [1].

Throughout a typical day, young children's movement includes sleep, sedentary time and light- to vigorousintensity physical activity, the latter mostly in the form of play, collectively referred to as 24-h movement behaviours. In 2019, the WHO released Global guidelines for these movement behaviours for children under 5 years of age [2]. The guidelines recommend that, during a 24h day, pre-school children (aged 3-4 years) accumulate at least $180 \mathrm{~min}(\mathrm{~min})$ physical activity (PA) - of which at least $60 \mathrm{~min}$ should be at moderate- to vigorousintensity (MVPA), engage in no more than $1 \mathrm{~h}$ sedentary screen time (e.g. television viewing, using a computer or tablets/smartphones while sitting) (SST), and have 10$13 \mathrm{~h}$ good-quality sleep per day [2] Appropriate levels of movement behaviours reduce the risk of obesity and non-communicable diseases, promote health [3-5], enhance mental wellbeing [6], and are a powerful antidote to stress and prevent viral infections [7]

A significant change in young children's lives during the COVID-19 restrictions is that they are not attending their usual places of early childhood education and care. Whether children have been able to meet movement behaviour guidelines during this time of COVID-19 restrictions is unknown, but it has been suggested that the restrictions may have considerable consequences for young children's ability to maintain a healthy balance of movement behaviours [8].

Over a 12-month period preceding the COVID-19 pandemic, we collected data on preschool children's movement behaviours in predominantly low- and middle-income countries (LMICs) as defined by the
World Bank [9]. This provided a baseline from which to determine the impact of the pandemic on children's movement behaviours. The aim of this study was to examine how, compared with the time period preCOVID, the COVID-19 pandemic influenced physical activity, sedentary behaviour, screen time, and sleep among pre-schoolers. Further, the study sought to examine the relationship between COVID-related restriction levels, parent and family factors, and changes in young children's physical activity, sedentary behaviour and sleep. We hypothesized that there would be i) increases in screen time, ii) decreases in physical activity, iii) changes in sleep patterns (bed, wake and nap times), and iv) that changes in movement behaviours would be associated with specific family and community-level COVID19 factors.

\section{Methods \\ Study design}

Prior to the COVID-19 pandemic, 14 countries (8 LMICs) collected data between April 2019 and March 2020 as part of the SUNRISE pilot study (https:// sunrise-study.com) to determine the proportion of 3and 4-year-old children who met the WHO Global guidelines. These countries conducted follow-up data collected between May-June 2020, with participants reporting on their experience at the height of prevention and control measures in their respective countries.

The research was performed in accordance with the Declaration of Helsinki. Overall research approval for the study was obtained from the Human Research Ethics Committee (Ref: 2018/044) from the University of Wollongong, Australia. Each wave of data collection was approved by the relevant Human Research Ethics Committees in each participating country.

\section{Setting}

Data were collected by local research teams in urban and rural settings, with participants recruited via early childhood education and care (ECEC) services and villages. At Time 1 (T1), parent survey were either conducted via interview, if there were literacy barriers, or self-administered. Follow-up (Time 2, T2) data 
collection was conducted via telephone interview or online survey via the Research Electronic Data Capture platform (REDCap) [10]

\section{Participants}

To be eligible for participation at $\mathrm{T} 1$, children were aged $\geq 3.0$ and $\leq 5.11$ years. To be eligible for participation at T2, data collection at T1 needed to have occurred within the preceding 12-months.

\section{Variables}

\section{Physical activity, sedentary time and sleep}

Primary parents reported their child's total physical activity (TPA), moderate- to vigorous-intensity physical activity, sedentary screen time, and the child's bed and wake times and nap duration, in hours and minutes per day, via survey (Table S1). Additional questions asked about screen device use before bedtime, screens in bedrooms, and sleep quality. Questions were based on the recommendations for each behaviour guideline [11] and then tested and refined as part of the SUNRISE pilot study, ensuring feasibility and acceptability among participating populations.

\section{Validation of PA questions}

Concurrent validity of the questions asking parents to report time spent in TPA and MVPA was evaluated using T1 data from Actigraph GT3X+ accelerometers on 436 and 377 participants, respectively (note: accelerometry data collected at $\mathrm{T} 1$ is not presented in this paper). Correlations were significant for TPA $(r=0.14$; $P=0.003)$ and for MVPA $(\mathrm{r}=0.16 ; P=0.002)$. Classification rates for meeting or not meeting the WHO Global guidelines based on Actigraph and parent-reported data were calculated. The sensitivity and specificity were 53 and $61 \%$ for TPA and 60 and $46 \%$ for MVPA, respectively.

\section{Demographics and COVID-19 factors}

Child age and sex and their parents' highest level of education were collected. Each country's Human Development Index and World Bank income classification were recorded and the data collection locations in each country were classified as urban or rural (Table S2).

In addition, the T2 survey included questions around the circumstances families faced during COVID-19 restrictions. These included parental working arrangements, type of housing, people per household, time spent outdoors, parental stress and exhaustion levels, parental efficacy in supporting their child to maintain healthy movement behaviours, support received from their early ECEC service, and resources accessed in the home. These were adapted from a similar survey [12].

\section{COVID-19 restrictions}

Data on six indicators of government responses to the Coronavirus pandemic, deemed relevant to the research questions, were obtained from the Oxford COVID-19 Government Response Tracker (OxCGRT) [13]. Two indicators, ability to go outside to exercise and playground closures were added. Each country checked if the tracker information was correct for the areas where data were collected at the height of restrictions (Table 1). Three categories of restrictions (low, moderate and high) were developed based on the variables deemed most influential on young children's movement behaviours in this context. These were ECEC closure and ability to go outside. A low level of restriction was defined as pre-school being open or available to children of essential workers, and the ability to go out in public for exercise. A moderate level of restriction as ECEC being closed and the recommendation to limit time outside, for example only within immediate residential area, specific times of day, maintaining physical distancing etc. A high level of restriction was applied to countries where ECECs were closed and people were not allowed to go out in public to exercise.

\section{Measurement}

Data collectors received training in how to administer the parent survey and use the REDCap [10] hosted at the University of Wollongong, Australia. Prior to participation, informed consent was obtained from the parents/legal guardians of participating children.

\section{Bias}

The results presented are based on the report of the child's primary carer, and as such there is a risk of recall bias. The internal validity of the dataset is strengthened given that for $86 \%$ of the sample, the same primary parent reported data at both time points. The response rate of $76 \%$ at $\mathrm{T} 2$ further reduces sample bias.

\section{Study size}

Power calculations were performed for meeting TPA and SST guidelines. Due to the sampling methods we accounted for within person and within ECEC service dependence of the outcomes. The intra-class correlations within ECEC services and within children were estimated $[14,15]$ and then converted to random effect variances. For each generated data set, a multi-level model was fitted with random intercepts for ECEC service, children, and the additional random slope $\beta_{k}$ for the change in outcomes from T1 to T2 in country k assuming that country effects varied according to the assumption $\beta_{k} \sim N\left(\beta, \sigma_{\beta}^{2}\right)$, with $\beta$ the mean change effect across countries. Finally, the significance of parameter $\beta$ 
Table 1 Key variables from the Oxford COVID-19 Government Response Tracker at the height of restrictions (OxCGRT)

\begin{tabular}{|c|c|c|c|c|c|c|c|c|}
\hline Country & $\begin{array}{l}\text { Preschool, } \\
\text { nursery, } \\
\text { school } \\
\text { closures }\end{array}$ & $\begin{array}{l}\text { Workplace } \\
\text { closures }\end{array}$ & $\begin{array}{l}\text { Public } \\
\text { transport } \\
\text { closure }\end{array}$ & $\begin{array}{l}\text { Restrictions on } \\
\text { domestic travel }\end{array}$ & $\begin{array}{l}\text { Stay at home } \\
\text { requirements }\end{array}$ & $\begin{array}{l}\text { Limit on private } \\
\text { gatherings (how } \\
\text { many people can } \\
\text { get together) }\end{array}$ & $\begin{array}{l}\text { Ability to go } \\
\text { outside for } \\
\text { exercise* }\end{array}$ & $\begin{array}{l}\text { Playground, } \\
\text { skate park } \\
\text { closures** }\end{array}$ \\
\hline Australia & $\begin{array}{l}\text { Kept open } \\
\text { for children } \\
\text { of essential } \\
\text { workers. }\end{array}$ & $\begin{array}{l}\text { Required } \\
\text { closing (or } \\
\text { work from } \\
\text { home) for } \\
\text { some sectors } \\
\text { or categories } \\
\text { of workers }\end{array}$ & No measures & $\begin{array}{l}\text { Internal } \\
\text { movement } \\
\text { restrictions in } \\
\text { place }\end{array}$ & $\begin{array}{l}\text { Require not } \\
\text { leaving house } \\
\text { with exceptions } \\
\text { for daily exercise, } \\
\text { grocery } \\
\text { shopping, and } \\
\text { 'essential' trips }\end{array}$ & $\begin{array}{l}\text { Restrictions on } \\
\text { gatherings of } 10 \\
\text { people or less }\end{array}$ & $\begin{array}{l}\text { Yes - for } \\
\text { exercise }\end{array}$ & All closed \\
\hline Bangladesh & $\begin{array}{l}\text { Required } \\
\text { closing }\end{array}$ & $\begin{array}{l}\text { Required } \\
\text { closing (or } \\
\text { work from } \\
\text { home) for } \\
\text { all-but- } \\
\text { essential } \\
\text { workplaces } \\
\text { (eg grocery } \\
\text { stores, } \\
\text { doctors) }\end{array}$ & $\begin{array}{l}\text { Required } \\
\text { closing (or } \\
\text { prohibit } \\
\text { most citizens } \\
\text { from using } \\
\text { it) }\end{array}$ & $\begin{array}{l}\text { Internal } \\
\text { movement } \\
\text { restrictions in } \\
\text { place }\end{array}$ & $\begin{array}{l}\text { Require not } \\
\text { leaving house } \\
\text { with exceptions } \\
\text { for daily exercise, } \\
\text { grocery } \\
\text { shopping, and } \\
\text { 'essential' trips }\end{array}$ & $\begin{array}{l}\text { Restrictions on } \\
\text { gatherings of } 10 \\
\text { people or less }\end{array}$ & Not allowed & All closed \\
\hline China & $\begin{array}{l}\text { Required } \\
\text { closing }\end{array}$ & $\begin{array}{l}\text { Required } \\
\text { closing (or } \\
\text { work from } \\
\text { home) for } \\
\text { all-but- } \\
\text { essential } \\
\text { workplaces } \\
\text { (eg grocery } \\
\text { stores, } \\
\text { doctors) }\end{array}$ & $\begin{array}{l}\text { Required } \\
\text { closing (or } \\
\text { prohibit } \\
\text { most citizens } \\
\text { from using } \\
\text { it) }\end{array}$ & $\begin{array}{l}\text { Internal } \\
\text { movement } \\
\text { restrictions in } \\
\text { place }\end{array}$ & $\begin{array}{l}\text { Require not } \\
\text { leaving house } \\
\text { with minimal } \\
\text { exceptions (eg } \\
\text { allowed to leave } \\
\text { once a week, or } \\
\text { only one person } \\
\text { can leave at a } \\
\text { time, etc) }\end{array}$ & $\begin{array}{l}\text { Restrictions on } \\
\text { gatherings of } 10 \\
\text { people or less }\end{array}$ & $\begin{array}{l}\text { Yes - but } \\
\text { encouraged to } \\
\text { reduce if } \\
\text { possible }\end{array}$ & $\begin{array}{l}\text { Partial } \\
\text { playground } \\
\text { and skate } \\
\text { park closures }\end{array}$ \\
\hline $\begin{array}{l}\text { Hong } \\
\text { Kong }\end{array}$ & $\begin{array}{l}\text { Required } \\
\text { closing }\end{array}$ & $\begin{array}{l}\text { Required } \\
\text { closing (or } \\
\text { work from } \\
\text { home) for } \\
\text { some sectors } \\
\text { or categories } \\
\text { of workers }\end{array}$ & No measures & No measures & $\begin{array}{l}\text { Recommend not } \\
\text { leaving house }\end{array}$ & $\begin{array}{l}\text { There was no limit } \\
\text { on how many } \\
\text { people can } \\
\text { congregate in } \\
\text { private settings or } \\
\text { at work, but not } \\
\text { allowed to } \\
\text { assemble in groups } \\
\text { of more than } 4 \text { for } \\
\text { public gatherings }\end{array}$ & $\begin{array}{l}\text { Yes, but leisure } \\
\text { venues for } \\
\text { public } \\
\text { gatherings were } \\
\text { closed }\end{array}$ & All closed \\
\hline India & $\begin{array}{l}\text { Required } \\
\text { closing }\end{array}$ & $\begin{array}{l}\text { Required } \\
\text { closing (or } \\
\text { work from } \\
\text { home) for } \\
\text { all-but- } \\
\text { essential } \\
\text { workplaces } \\
\text { (eg grocery } \\
\text { stores, } \\
\text { doctors) }\end{array}$ & $\begin{array}{l}\text { Required } \\
\text { closing (only } \\
\text { open for } \\
\text { emergency } \\
\text { services) }\end{array}$ & $\begin{array}{l}\text { Internal } \\
\text { movement not } \\
\text { allowed except } \\
\text { for emergency } \\
\text { with prior } \\
\text { permission of } \\
\text { police }\end{array}$ & $\begin{array}{l}\text { Require not } \\
\text { leaving house } \\
\text { with minimal } \\
\text { exceptions (eg } \\
\text { allowed to leave } \\
\text { once a week, or } \\
\text { only one person } \\
\text { can leave at a } \\
\text { time) }\end{array}$ & $\begin{array}{l}\text { Restrictions on } \\
\text { gatherings of } 10 \\
\text { people or less }\end{array}$ & Not Allowed & All closed \\
\hline Indonesia & $\begin{array}{l}\text { Required } \\
\text { closing }\end{array}$ & $\begin{array}{l}\text { Required } \\
\text { closing (or } \\
\text { work from } \\
\text { home) for } \\
\text { some sectors } \\
\text { or categories } \\
\text { of workers }\end{array}$ & $\begin{array}{l}\text { Recommend } \\
\text { closing (or } \\
\text { significantly } \\
\text { reduce } \\
\text { volume } \\
\text { /route/ } \\
\text { means of } \\
\text { transport } \\
\text { available) }\end{array}$ & $\begin{array}{l}\text { Internal } \\
\text { movement } \\
\text { restrictions in } \\
\text { place }\end{array}$ & $\begin{array}{l}\text { Require not } \\
\text { leaving house } \\
\text { with exceptions } \\
\text { for daily exercise, } \\
\text { grocery } \\
\text { shopping, and } \\
\text { 'essential' trips }\end{array}$ & $\begin{array}{l}\text { Restrictions on } \\
\text { gatherings of } 10 \\
\text { people or less }\end{array}$ & $\begin{array}{l}\text { Yes - for } \\
\text { exercise }\end{array}$ & All closed \\
\hline Malaysia & $\begin{array}{l}\text { Required } \\
\text { closing }\end{array}$ & $\begin{array}{l}\text { Required } \\
\text { closing (or } \\
\text { work from } \\
\text { home) for } \\
\text { all-but- } \\
\text { essential }\end{array}$ & No measures & $\begin{array}{l}\text { Internal } \\
\text { movement } \\
\text { restrictions in } \\
\text { place }\end{array}$ & $\begin{array}{l}\text { Recommend not } \\
\text { leaving house }\end{array}$ & $\begin{array}{l}\text { Restrictions on } \\
\text { gatherings } \\
\text { between } 50 \text { people }\end{array}$ & Not allowed & All closed \\
\hline
\end{tabular}


Table 1 Key variables from the Oxford COVID-19 Government Response Tracker at the height of restrictions (OxCGRT) (Continued)

\begin{tabular}{|c|c|c|c|c|c|c|c|c|}
\hline Country & $\begin{array}{l}\text { Preschool, } \\
\text { nursery, } \\
\text { school } \\
\text { closures }\end{array}$ & $\begin{array}{l}\text { Workplace } \\
\text { closures }\end{array}$ & $\begin{array}{l}\text { Public } \\
\text { transport } \\
\text { closure }\end{array}$ & $\begin{array}{l}\text { Restrictions on } \\
\text { domestic travel }\end{array}$ & $\begin{array}{l}\text { Stay at home } \\
\text { requirements }\end{array}$ & $\begin{array}{l}\text { Limit on private } \\
\text { gatherings (how } \\
\text { many people can } \\
\text { get together) }\end{array}$ & $\begin{array}{l}\text { Ability to go } \\
\text { outside for } \\
\text { exercise* }\end{array}$ & $\begin{array}{l}\text { Playground, } \\
\text { skate park } \\
\text { closures** }\end{array}$ \\
\hline & & $\begin{array}{l}\text { workplaces } \\
\text { (eg grocery } \\
\text { stores, } \\
\text { doctors) }\end{array}$ & & & & & & \\
\hline Morocco & $\begin{array}{l}\text { Stop } \\
\text { teaching at } \\
\text { all levels, } \\
\text { public }\end{array}$ & $\begin{array}{l}\text { Required } \\
\text { closing (or } \\
\text { work from } \\
\text { home) for } \\
\text { all-but- } \\
\text { essential } \\
\text { workplaces } \\
\text { (eg grocery } \\
\text { stores, } \\
\text { doctors) }\end{array}$ & $\begin{array}{l}\text { Required } \\
\text { closing (or } \\
\text { prohibit } \\
\text { most citizens } \\
\text { from using } \\
\text { it) }\end{array}$ & $\begin{array}{l}\text { limitation of } \\
\text { travel between } \\
\text { neighbourhood, } \\
\text { regions and } \\
\text { between cities }\end{array}$ & $\begin{array}{l}\text { Leaving house } \\
\text { not allowed with } \\
\text { exceptions for } \\
\text { health } \\
\text { emergency, } \\
\text { grocery } \\
\text { shopping, and } \\
\text { 'essential' trips }\end{array}$ & $\begin{array}{l}\text { Prohibition of } \\
\text { professional and } \\
\text { private gatherings } \\
\text { Professional } \\
\text { meetings to be } \\
\text { limited except nb. } \\
\text { Limited and } \\
\text { respecting the } \\
\text { safety instructions }\end{array}$ & Not allowed & All closed \\
\hline Pakistan & $\begin{array}{l}\text { Required } \\
\text { closing }\end{array}$ & $\begin{array}{l}\text { Required } \\
\text { closing (or } \\
\text { work from } \\
\text { home) for } \\
\text { all-but- } \\
\text { essential } \\
\text { workplaces } \\
\text { (eg grocery } \\
\text { stores, } \\
\text { doctors) }\end{array}$ & $\begin{array}{l}\text { Required } \\
\text { closing (or } \\
\text { prohibit } \\
\text { most citizens } \\
\text { from using } \\
\text { it) }\end{array}$ & $\begin{array}{l}\text { Internal } \\
\text { movement } \\
\text { restrictions in } \\
\text { place }\end{array}$ & $\begin{array}{l}\text { Require not } \\
\text { leaving house } \\
\text { with exceptions } \\
\text { for daily exercise, } \\
\text { grocery } \\
\text { shopping, and } \\
\text { 'essential' trips }\end{array}$ & $\begin{array}{l}\text { Restrictions on } \\
\text { gatherings of } 10 \\
\text { people or less }\end{array}$ & $\begin{array}{l}\text { Allowed only } \\
\text { until } 5 \mathrm{pm}\end{array}$ & All closed \\
\hline Spain & $\begin{array}{l}\text { Required } \\
\text { closing }\end{array}$ & $\begin{array}{l}\text { Required } \\
\text { closing (or } \\
\text { work from } \\
\text { home) for } \\
\text { all-but- } \\
\text { essential } \\
\text { workplaces } \\
\text { (eg grocery } \\
\text { stores, } \\
\text { doctors) }\end{array}$ & $\begin{array}{l}\text { Recommend } \\
\text { closing (or } \\
\text { significantly } \\
\text { reduce } \\
\text { volume } \\
\text { /route/ } \\
\text { means of } \\
\text { transport } \\
\text { available) }\end{array}$ & $\begin{array}{l}\text { Internal } \\
\text { movement } \\
\text { restrictions in } \\
\text { place }\end{array}$ & $\begin{array}{l}\text { Require not } \\
\text { leaving house } \\
\text { with exceptions } \\
\text { for grocery } \\
\text { shopping and } \\
\text { 'essential' trips }\end{array}$ & $\begin{array}{l}\text { Restrictions on } \\
\text { gatherings of } 10 \\
\text { people or less }\end{array}$ & Not allowed & All closed \\
\hline Sri Lanka & $\begin{array}{l}\text { Required } \\
\text { closing }\end{array}$ & $\begin{array}{l}\text { Required } \\
\text { closing (or } \\
\text { work from } \\
\text { home) for } \\
\text { all-but- } \\
\text { essential } \\
\text { workplaces } \\
\text { (eg grocery } \\
\text { stores, } \\
\text { doctors) }\end{array}$ & $\begin{array}{l}\text { Required } \\
\text { closing (or } \\
\text { prohibit } \\
\text { most citizens } \\
\text { from using } \\
\text { it) }\end{array}$ & $\begin{array}{l}\text { Internal } \\
\text { movement } \\
\text { restrictions in } \\
\text { place }\end{array}$ & $\begin{array}{l}\text { Require not } \\
\text { leaving house } \\
\text { with minimal } \\
\text { exceptions (eg } \\
\text { allowed to leave } \\
\text { once a week, or } \\
\text { only one person } \\
\text { can leave at a } \\
\text { time) }\end{array}$ & $\begin{array}{l}\text { Restrictions on } \\
\text { gatherings of } 10 \\
\text { people or less }\end{array}$ & Not allowed & All closed \\
\hline Sweden & $\begin{array}{l}\text { Preschool } \\
\text { open. }\end{array}$ & $\begin{array}{l}\text { Recommend } \\
\text { closing (or } \\
\text { recommend } \\
\text { work from } \\
\text { home) }\end{array}$ & $\begin{array}{l}\text { No closure, } \\
\text { however, } \\
\text { fewer people } \\
\text { per vehicle } \\
\text { encouraged }\end{array}$ & $\begin{array}{l}\text { Recommend } \\
\text { not to travel } \\
\text { between } \\
\text { regions/cities (> } \\
2 \mathrm{~h} \text { from home) }\end{array}$ & $\begin{array}{l}\text { No } \\
\text { recommendation }\end{array}$ & $\begin{array}{l}\text { Restrictions on } \\
\text { gatherings } \\
\text { between } 50 \text { people }\end{array}$ & Yes-allowed & All open \\
\hline $\begin{array}{l}\text { United } \\
\text { States }\end{array}$ & $\begin{array}{l}\text { Kept open } \\
\text { for children } \\
\text { of essential } \\
\text { workers. } \\
\text { The } \\
\text { majority of } \\
\text { children } \\
\text { stayed at } \\
\text { home }\end{array}$ & $\begin{array}{l}\text { Required } \\
\text { closing (or } \\
\text { work from } \\
\text { home) for } \\
\text { all-but- } \\
\text { essential } \\
\text { workplaces } \\
\text { (eg grocery } \\
\text { stores, } \\
\text { doctors) }\end{array}$ & $\begin{array}{l}\text { Recommend } \\
\text { closing (or } \\
\text { significantly } \\
\text { reduce } \\
\text { volume } \\
\text { /route/ } \\
\text { means of } \\
\text { transport } \\
\text { available) }\end{array}$ & $\begin{array}{l}\text { Internal } \\
\text { movement } \\
\text { restrictions in } \\
\text { place }\end{array}$ & $\begin{array}{l}\text { Require not } \\
\text { leaving house } \\
\text { with exceptions } \\
\text { for daily exercise, } \\
\text { grocery } \\
\text { shopping, and } \\
\text { 'essential' trips }\end{array}$ & $\begin{array}{l}\text { Restrictions on } \\
\text { gatherings of } 10 \\
\text { people or less }\end{array}$ & $\begin{array}{l}\text { Yes - "Take a } \\
\text { walk, ride your } \\
\text { bike, hike, jog } \\
\text { and be in } \\
\text { nature for } \\
\text { exercise - just } \\
\text { keep at least } 6 \\
\text { feet between } \\
\text { you and others." }\end{array}$ & All closed \\
\hline Vietnam & $\begin{array}{l}\text { Required } \\
\text { closures }\end{array}$ & $\begin{array}{l}\text { Required } \\
\text { closing (or }\end{array}$ & $\begin{array}{l}\text { Required } \\
\text { closing (or }\end{array}$ & $\begin{array}{l}\text { Internal } \\
\text { movement }\end{array}$ & $\begin{array}{l}\text { Require not } \\
\text { leaving house }\end{array}$ & $\begin{array}{l}\text { Restrictions on } \\
\text { gatherings of } 2\end{array}$ & $\begin{array}{l}\text { Yes - but } \\
\text { encouraged to }\end{array}$ & All closed \\
\hline
\end{tabular}


Table 1 Key variables from the Oxford COVID-19 Government Response Tracker at the height of restrictions (OxCGRT) (Continued)

\begin{tabular}{|c|c|c|c|c|c|c|c|c|}
\hline Country & $\begin{array}{l}\text { Preschool, } \\
\text { nursery, } \\
\text { school } \\
\text { closures }\end{array}$ & $\begin{array}{l}\text { Workplace } \\
\text { closures }\end{array}$ & $\begin{array}{l}\text { Public } \\
\text { transport } \\
\text { closure }\end{array}$ & $\begin{array}{l}\text { Restrictions on } \\
\text { domestic travel }\end{array}$ & $\begin{array}{l}\text { Stay at home } \\
\text { requirements }\end{array}$ & $\begin{array}{l}\text { Limit on private } \\
\text { gatherings (how } \\
\text { many people can } \\
\text { get together) }\end{array}$ & $\begin{array}{l}\text { Ability to go } \\
\text { outside for } \\
\text { exercise* }\end{array}$ & $\begin{array}{l}\text { Playground, } \\
\text { skate park } \\
\text { closures** }\end{array}$ \\
\hline & & $\begin{array}{l}\text { work from } \\
\text { home) for } \\
\text { all-but- } \\
\text { essential } \\
\text { workplaces } \\
\text { (eg grocery } \\
\text { stores, } \\
\text { doctors) }\end{array}$ & $\begin{array}{l}\text { prohibit } \\
\text { most citizens } \\
\text { from using } \\
\text { it) }\end{array}$ & $\begin{array}{l}\text { restrictions in } \\
\text { place }\end{array}$ & $\begin{array}{l}\text { with exceptions } \\
\text { for daily exercise, } \\
\text { grocery } \\
\text { shopping, and } \\
\text { 'essential' trips }\end{array}$ & $\begin{array}{l}\text { people or less at } \\
\text { public places } \\
\text { outside workplace, } \\
\text { schools, hospitals; } \\
2 \text { m distancing }\end{array}$ & $\begin{array}{l}\text { reduce if } \\
\text { possible }\end{array}$ & \\
\hline
\end{tabular}

*As reported by the $\mathrm{Cl}$ in each country. ** Based on a combination of ECEC closure and ability to go outside

was tested. The estimated power was $\geq 80 \%$ for meeting both the TPA and SST guidelines. All analyses were conducted using $\mathrm{R}$ [16] and $\mathrm{R}$ package lmer [17] with optimizer "bobyqa" used to fit the multi-level models. Missing data were ignored and not imputed; that is, missingness was assumed to be at random.

\section{Statistical methods}

Descriptive data were calculated as frequencies (\%) or means with 95\% confidence intervals (CI, using Wald type confidence interval). Results were presented for the effect $\beta$ as average or effect across countries with corresponding $95 \%$ CIs or as average mean change across countries with corresponding 95\% CIs. Coefficients were based on a multi-level model with ECEC services as random effects (accounting for cluster sampling), children as random effects (accounting for paired data) and country random effects of change from $\mathrm{T} 1$ to $\mathrm{T} 2$.

A linear mixed model was fitted to the difference of outcomes at T2 relative to T1. Models similar to the multi-level models for the descriptive results were fitted without the child random effects, as there was only one observation per child. For the outcomes of meeting the guidelines at T2, a logistic multi-level regression model was fitted accounting for T1 with ECEC service and country sites as random effects.

\section{Results}

\section{Participants}

The final analytical sample comprised 948 respondents (children's mean age $\mathrm{T} 1=4.4$ years, standard deviation $(\mathrm{SD})=0.6 ; \mathrm{T} 2=5.2$ years, $\mathrm{SD}=0.6$ ). The average response rate for the sample was $76 \%$, and the average time interval between $\mathrm{T} 1$ and $\mathrm{T} 2$ was 9.6 months $(\mathrm{SD}=$ 3.8 ). Of the children, $49 \%$ were female, $39 \%$ lived in rural areas, $71 \%$ were from LMICs, and $63 \%$ of parents had some level of tertiary education (Table S3). Eighty-three percent of children went outside during COVID-19 restrictions (see Table 2 for duration), and 59\% lived in housing with access to an outside play area in the form of private garden/yard, or communal park/green or open space near their house (Table S4).

At the height of COVID-19 restrictions, $41 \%$ of the participants faced high, $46 \%$ moderate, and 13\% low levels of restrictions. Fifty-three percent, 59, and 47\% of parents were concerned about their child's level of physical activity, sedentary behaviour and sleep, respectively. Around $80 \%$ of parents felt able to support their child to have healthy movement behaviours and had received resources from their child's ECEC service and 62\% had accessed online resources to support their child's movement behaviours at home. Around one-third of parents reported that they felt more stressed and exhausted than before COVID-19 (Table S4).

Table 2 presents the changes in children's movement behaviour patterns before and during COVID-19. Overall, children spent $55 \mathrm{~min} /$ day more $(p<0.0001)$ in SST and the proportion who met the SST guideline dropped from 48 to $25 \%(p<0.0001)$. Children went to bed 34 min later $(p=0.003)$ and woke up 60 min later $(p<0.0005)$ than before COVID-19. The mean nap time decreased by $19 \mathrm{~min} /$ day $(p=0.020)$. Children spent $81 \mathrm{~min}(p=0.021)$ and 105 $\min (p=0.003)$ less time outdoors on weekdays and weekend days, respectively. No significant changes were observed in other behavioural variables.

Table 3 reports the associations between selected COVID-19 factors and changes in time spent in movement behaviours. Children whose parents were concerned about their child's movement behaviours had a significantly greater increase in SST compared with parents who were not concerned (regression coefficient = 14.9; 95\% CI 0.2-29.6). Children who lived in houses with outdoor spaces had a significantly greater increase in TPA (coefficient $=54.7 ; 95 \%$ CI 19.0-90.3) ) and a smaller decrease in MVPA (-coefficient $=16.7 ; 95 \% \mathrm{CI}$ 1.0-32.3)), compared with those with no outdoor space. Children whose parents reported receiving support from their ECEC service during COVID had a significantly smaller decrease in sleep duration (coefficient $=29.8$; 95\% CI 8.1-51.6) than those children whose service did not provide support to parents. 
Table 2 Changes in young children's movement behaviours and sleep characteristics before (T1) and during COVID-19 (T2)

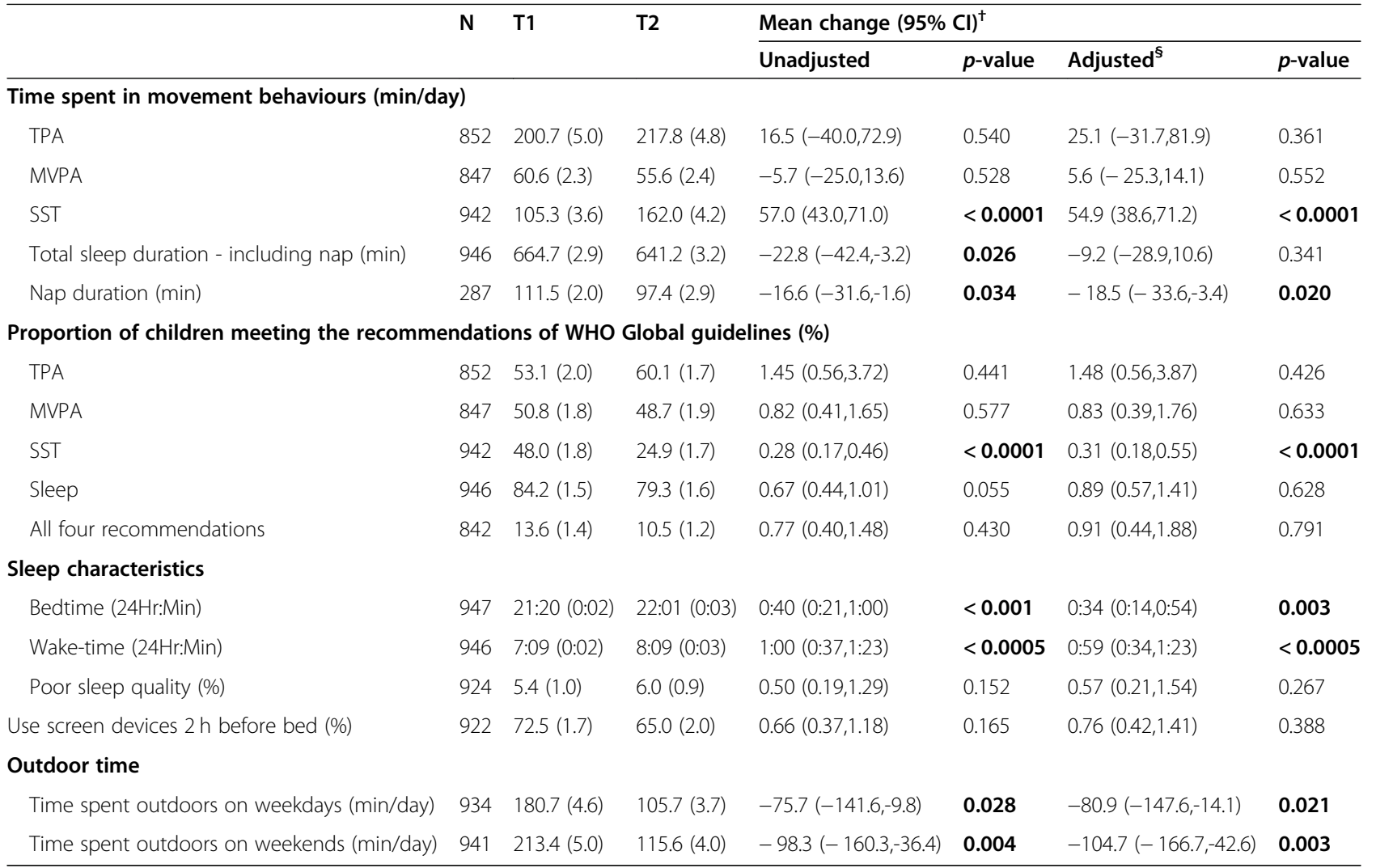

TPA total physical activity, MVPA moderate-to-vigorous intensity physical activity, SST sedentary screen time

Data are presented as mean (standard error) for continuous variables or percentage (standard error) for categorical variables. Bold value indicates statistically significant effect $(p<0.05)$

${ }^{\dagger}$ Mean change effects are presented in min/day format for continuous variables or odds ratio for categorical variables.

${ }^{\S}$ Adjusted for age by sex interaction, rurality, change in parent relationship to child (person who completed the survey), childcare centre (as random effects), country sites (as random effects), and parents' highest level of education.

Table 4 reports the associations between selected COVID-19 factors and meeting the WHO Global guidelines during COVID-19. Only the factors that showed a significant association in the fully adjusted models (Table 4, Model 2) are reported. Compared with countries with a high level of restrictions, children in countries with a low level were 3.59 times more likely to meet the MVPA guideline (95\%Confidence Interval [CI] $1.39,9.30)$ and 6.71 times more likely to meet the sleep guideline $(95 \% \mathrm{CI} 1.77,25.46)$; whereas children in countries with a moderate level of restrictions were 2.71 times more likely to meet the SST guideline $(95 \% \mathrm{CI}$ 1.56, 4.70). Children from LMICs were 12.17 times more likely to meet the TPA $(95 \%$ CI 3.03, 49.00), 1.96 times more likely to meet the MVPA $(95 \%$ CI $1.02,3.77)$ and 2.16 times more likely to meet the SST guidelines $(95 \%$ CI 1.19, 3.94) than children from HICs. Compared with children who were not allowed to go outside, those who were allowed were 3.3 times more likely to meet all four guidelines $(95 \% \mathrm{CI} 1.12,9.76)$ and 1.7 times more likely to meet the TPA guideline $(95 \% \mathrm{CI} 1.05,2.75)$.
Compared with parents who were not concerned about their child's movement behaviours, children of parents who were concerned were half as likely to meet the TPA $(95 \% \mathrm{CI} 0.34,0.74)$ and two-thirds less likely to meet the SST guidelines (95\%CI 0.47 , 0.96). However, children whose parents believed they had the ability to support their child's movement behaviours were 1.89 times more likely to meet the MVPA guidelines compared with those who did not believe this $(95 \%$ CI 1.17, 3.06). Compared with children who lived in houses with no outdoor play spaces, children in houses with outdoor play spaces were 2.41 times more likely to meet the TPA $(95 \% \mathrm{CI} 1.32,4.41)$ and 2.61 times more likely to meet the MVPA guidelines (95\%CI 1.56, 4.36). Children whose parents felt more exhausted at the time of the survey compared with before COVID-19 were 0.59 times less likely to meet the sleep guideline than children whose parents felt less or the same level of exhaustion $(95 \% \mathrm{CI}$ $0.37,0.95)$. 
Table 3 Linear regression of associations between changes in movement behaviours and selected COVID-19 factors

\begin{tabular}{|c|c|c|c|c|c|c|c|c|}
\hline \multirow[t]{3}{*}{ COVID-19 factors } & \multicolumn{8}{|c|}{ Changes in time spent in movement behaviours } \\
\hline & \multicolumn{2}{|l|}{ TPA } & \multicolumn{2}{|l|}{ MVPA } & \multicolumn{2}{|l|}{ SST } & \multicolumn{2}{|c|}{ Sleep duration } \\
\hline & Model 1 & Model 2 & Model 1 & Model 2 & Model 1 & Model 2 & Model 1 & Model 2 \\
\hline \multicolumn{9}{|l|}{ Level of restrictions } \\
\hline High (Ref) & - & - & - & - & - & - & - & - \\
\hline Low & $\begin{array}{l}6.3(- \\
185.1197 .7)\end{array}$ & $\begin{array}{l}52.9(-160.0 \\
265.8)\end{array}$ & $\begin{array}{l}27.7(-25.2, \\
80.7)\end{array}$ & $\begin{array}{l}36.9 \\
(-31.4105 .2)\end{array}$ & $\begin{array}{l}-9.7(-50.0, \\
30.6)\end{array}$ & $\begin{array}{l}-4.6(-60.3, \\
51.1)\end{array}$ & $\begin{array}{l}-14.6(-70.1, \\
40.9)\end{array}$ & $\begin{array}{l}-10.4(-98.1 \\
77.4)\end{array}$ \\
\hline Moderate & $\begin{array}{l}-17.7(- \\
193.1157 .7)\end{array}$ & $\begin{array}{l}10.1(-137.0 \\
157.2)\end{array}$ & $\begin{array}{l}4.4(-43.9 \\
52.7)\end{array}$ & $\begin{array}{l}6.3(-40.8 \\
53.3)\end{array}$ & $\begin{array}{l}-18.0(-52.8, \\
16.7)\end{array}$ & $\begin{array}{l}-22.5(-59.2 \\
14.2)\end{array}$ & $\begin{array}{l}-4.7(-52.4 \\
43.0)\end{array}$ & $\begin{array}{l}-28.2(-83.6, \\
27.2)\end{array}$ \\
\hline \multicolumn{9}{|l|}{ Country income level } \\
\hline $\begin{array}{l}\text { High-income (HIC) } \\
\text { (Ref) }\end{array}$ & - & - & - & - & - & - & - & - \\
\hline $\begin{array}{l}\text { Low/middle-income } \\
\text { (LMIC) }\end{array}$ & $\begin{array}{l}44.1(-96.0 \\
184.2)\end{array}$ & $\begin{array}{l}78.1 \\
(-96.7252 .9)\end{array}$ & $\begin{array}{l}0.7(-41.9 \\
43.4)\end{array}$ & $\begin{array}{l}22.6(-33.2, \\
78.5)\end{array}$ & $\begin{array}{l}-11.5(-41.9, \\
18.9)\end{array}$ & $\begin{array}{l}-10.9(-54.4 \\
32.6)\end{array}$ & $\begin{array}{l}21.5(-17.7 \\
60.6)\end{array}$ & $\begin{array}{l}21.8(-48.7, \\
92.3)\end{array}$ \\
\hline \multicolumn{9}{|c|}{ Go outside during COVID-19 } \\
\hline No (Ref) & - & - & - & - & - & - & - & - \\
\hline Yes & $7.1(-22.6,36.9)$ & $\begin{array}{l}9.3(-20.9 \\
39.4)\end{array}$ & $\begin{array}{l}5.5(-7.2 \\
18.3)\end{array}$ & $\begin{array}{l}6.0(-7.2 \\
19.2)\end{array}$ & $\begin{array}{l}2.0(-16.1 \\
20.1)\end{array}$ & $\begin{array}{l}5.8(-12.9 \\
24.5)\end{array}$ & $\begin{array}{l}4.1(-11.6, \\
19.7)\end{array}$ & $\begin{array}{l}4.1(-11.6, \\
19.7)\end{array}$ \\
\hline \multicolumn{9}{|c|}{ Parent's concern about child's movement behaviour ${ }^{\S}$} \\
\hline No (Ref) & - & - & N/A & N/A & - & - & - & - \\
\hline Yes & $\begin{array}{l}-24.1(-48.2 \\
0.06)\end{array}$ & $\begin{array}{l}-23.0(-47.4, \\
1.4)\end{array}$ & & & $\begin{array}{l}15.7(1.6 \\
19.7)\end{array}$ & $\begin{array}{l}14.9(0.2, \\
29.6)\end{array}$ & $4.7(-8.2,17.7)$ & $4.3(-8.9,17.5)$ \\
\hline \multicolumn{9}{|c|}{ Parent's perceived ability to support child to have healthy movement behaviours } \\
\hline No (Ref) & - & - & - & - & - & - & - & - \\
\hline Yes & $\begin{array}{l}-7.8(-36.6, \\
21.0)\end{array}$ & $\begin{array}{l}-10.2(-39.0 \\
18.5)\end{array}$ & $\begin{array}{l}8.6(-3.9, \\
21.0)\end{array}$ & $\begin{array}{l}7.4(-5.2 \\
20.0)\end{array}$ & $\begin{array}{l}-10.1(-27.1 \\
6.9)\end{array}$ & $\begin{array}{l}-4.4(-21.8 \\
13.1)\end{array}$ & $5.6(-9.2,20.4)$ & $5.7(-9.1,20.4)$ \\
\hline
\end{tabular}

Presence of outdoor space within house compound

$\begin{array}{lll}\text { No (Ref) } & - & - \\ \text { Yes } & \mathbf{5 0 . 9}(\mathbf{1 6 . 5}, & \mathbf{5 4 . 7}(\mathbf{1 9 . 0}, \\ & \mathbf{8 5 . 4}) & \mathbf{9 0 . 3})\end{array}$

$17.1(2.5$

$16.7(1.0$ 31.8) 32.3)

$-15.6(-33.9$

$-16.9(-37.6$

Number of adults living within the same household

3.8)

$1.6(-15.6$

$1.0(-17.0$

Two or less (Ref)

More than two

$$
\begin{array}{ll}
5.3(-18.1,28.6) & 3.9(-19.4 \\
& 27.2)
\end{array}
$$

$-2.6(-12.8, \quad-3.3(-13.7, \quad 1.5(-15.3$,

12.3)

$-0.8(-15.2$

13.6)

18.7)

19.0)

Number of children living within the same household

Two or less (Ref)
More than two

$$
\begin{array}{ll}
22.5(-6.6,51.6) & 25.2(-4.1, \\
& 54.4)
\end{array}
$$

$2.5(-10.1$,

15.1)

$3.2(-9.7$,

16.1)

$-2.5(-19.3$,

14.2)

$0.0(-17.3$

17.3)

$-2.6(-17.2$,

$-2.6(-17.3$

Parent's perceived level of stress compared to before COVID-19

Less/about the

same (Ref)

More stressed

$$
\begin{array}{ll}
-11.5(-36.4, & -1.4(-29.6, \\
13.5) & 26.8)
\end{array}
$$$$
-4.9(-15.7,-8.4(-21.0, \quad \mathbf{1 5 . 0}(\mathbf{0 . 4},
$$$$
5.9)
$$

4.1)

29.6)

$8.2(-8.8,25.3)$

$-1.7(-14.5$

$4.0(-10.5$

Parent's perceived level of exhaustion compared to before COVID-19

Less/about the

same (Ref)

More exhausted

$$
\begin{array}{lll}
-10.6(-35.2, & -5.4(-33.2, & 3.8(-6.8, \\
14.0) & 22.3) & 14.4)
\end{array}
$$

$8.2(-4.0$

20.4)
$13.3(-1.2$ 27.8)
$6.1(-10.5$, 22.7)

$-12.8(-$

25.4,-0.2)

$-13.3(-27.4$

Receiving any support from childcare centre

No (Ref) 
Table 3 Linear regression of associations between changes in movement behaviours and selected COVID-19 factors (Continued)

\begin{tabular}{|c|c|c|c|c|c|c|c|c|}
\hline \multirow[t]{3}{*}{ COVID-19 factors } & \multicolumn{8}{|c|}{ Changes in time spent in movement behaviours } \\
\hline & \multicolumn{2}{|l|}{ TPA } & \multicolumn{2}{|l|}{ MVPA } & \multicolumn{2}{|l|}{ SST } & \multicolumn{2}{|l|}{ Sleep duration } \\
\hline & Model 1 & Model 2 & Model 1 & Model 2 & Model 1 & Model 2 & Model 1 & Model 2 \\
\hline Yes & $\begin{array}{l}-8.2(-51.5 \\
35.1)\end{array}$ & $\begin{array}{l}-8.2(-53.7 \\
37.4)\end{array}$ & $\begin{array}{l}-2.0(-20.0 \\
16.0)\end{array}$ & $\begin{array}{l}-0.1(-19.4, \\
19.1)\end{array}$ & $\begin{array}{l}-22.6(- \\
45.9,0.7)\end{array}$ & $\begin{array}{l}-21.7(-47.5 \\
4.1)\end{array}$ & $\begin{array}{l}22.3(1.2, \\
43.4)\end{array}$ & $\begin{array}{l}29.8(8.1, \\
51.6)\end{array}$ \\
\hline \multicolumn{9}{|c|}{ Using any resources to support/facilitate child's movement behaviours at home } \\
\hline No (Ref) & - & - & - & - & - & - & - & - \\
\hline Yes & $2.7(-23.2,28.5)$ & $\begin{array}{l}7.2(-19.0 \\
33.5)\end{array}$ & $\begin{array}{l}0.8(-10.3 \\
11.9)\end{array}$ & $\begin{array}{l}0.3(-11.2 \\
11.8)\end{array}$ & $\begin{array}{l}4.4(-11.0 \\
19.9)\end{array}$ & $\begin{array}{l}3.2(-13.0 \\
19.5)\end{array}$ & $4.8(-8.9,18.6)$ & $5.0(-8.9,18.9)$ \\
\hline
\end{tabular}

TPA total physical activity, MVPA moderate-to-vigorous intensity physical activity, SST sedentary screen time

Data are presented as unstandardized regression coefficients (95\% confidence interval); bold value indicates statistically significant effect

Model 1: Adjusted for age (at T2) by sex interaction, change in age (T2 relative to T1), rurality, change in parent relationship to child (person who completed the

survey), childcare centre (as random effects), country sites (as random effects), parents' highest level of education, and children who reported as sick at T2

(preventing from being active at T2)

Model 2: Included all variables in Model 1 and all COVID-19 factors

${ }^{\S}$ Separate questions were asked for total physical activity, sitting (including screen time) and sleep, but not for MVPA

\section{Discussion}

The purpose of this study was to examine how, compared with the time period pre-COVID, the restrictions of the COVID-19 pandemic influenced physical activity, sedentary screen time and sleep among pre-schoolers.

\section{Key results summary}

We hypothesised that, compared with pre-COVID-19, there would be increases in SST, decreases in PA and changes in sleep patterns among young children at the height of COVID-19 restrictions. These hypotheses were confirmed except for PA levels. Family and community factors that were associated with changes in movement behaviours included the presence of an outdoor space to play within the home compound, a supportive ECEC service, and parental stress and exhaustion levels. Additional factors that were associated with a greater likelihood of meeting WHO Global guidelines during COVID-19 included living in a LMIC, living in a country with lower levels of restrictions, being able to go outside, having more than two adults living in the house, and having parents who were less concerned about their child's movement behaviours.

The small changes in PA were surprising and contrary to findings that have reported large declines in PA during the pandemic period among older children $[12,18$, 19]. These differences may be explained methodologically. Our study used a longitudinal design with parents reporting their children's current activity levels at a particular point in time while the others were crosssectional where parents retrospectively reported what changes may have occurred from pre-COVID to during COVID-19, often in the form of Likert scale (more or less active than before), without parents having to quantify the changes. Data reported this way has a greater chance of emotional bias (parents more likely to see things negatively compared with before), especially given the higher level of parent stress and exhaustion during COVID-19. These smaller changes can be explained by more parents being at home during COVID-19 and spending more time with their child, and children getting more time to play due to closure of ECEC services. As children in our study were not attending ECEC and not participating in any structured learning activities they had more time for active play and in home environments that were more conducive to promoting activity than the environments in ECEC services.

The significant increase in SST during the COVID-19 period is consistent with other studies among children $[12,18-20]$. This is largely due to children spending less time outdoors and in some countries undertaking activities online while at home. Other factors might include parents working from home and using electronic media devices to keep their child busy while they worked. A concern here is that only half the children met the SST guidelines before COVID-19. This proportion almost halved during the pandemic, thereby considerably increasing sedentary time in addition to the increase in screen-time. Although not all SST is detrimental [21] (e.g educational apps, face-time with relatives), the low compliance with SST recommendations during COVID should raise concern for the potential negative consequences for young children that may result from engaging in SST in excess of the guidelines, both from a screen time and sedentary time perspective.

There was no change in total sleep duration, unlike among school-aged children and youth who reportedly slept more during the restriction [12]. Reasons for the observed changes in sleep patterns may include children choosing not to nap at home, unlike when attending ECEC where they are required to nap or rest quietly. Parents reported that children slept for longer in the morning, were less tired in the afternoon and therefore they did not nap. There was probably more flexibility 
Table 4 Logistic regression of associations between meeting WHO Global guidelines and selected COVID-19 factors

\begin{tabular}{|c|c|c|c|c|c|c|c|c|c|c|}
\hline & \multicolumn{2}{|c|}{ TPA guideline } & \multicolumn{2}{|c|}{ MVPA guideline } & \multicolumn{2}{|c|}{ SST guideline } & \multicolumn{2}{|c|}{ Sleep guideline } & \multicolumn{2}{|c|}{ All guidelines } \\
\hline & Model 1 & Model 2 & Model 1 & Model 2 & Model 1 & Model 2 & Model 1 & Model 2 & Model 1 & Model 2 \\
\hline \multicolumn{11}{|l|}{ Level of restrictions } \\
\hline High (Ref) & 1.00 & 1.00 & 1.00 & 1.00 & 1.00 & 1.00 & 1.00 & 1.00 & 1.00 & 1.00 \\
\hline Low & $\begin{array}{l}0.94(0.11 \\
7.83)\end{array}$ & $\begin{array}{l}4.29(0.74 \\
24.90)\end{array}$ & $\begin{array}{l}4.43(1.77, \\
11.12)\end{array}$ & $\begin{array}{l}3.59 \\
(1.39 \\
9.30)\end{array}$ & $\begin{array}{l}1.13(0.52, \\
2.44)\end{array}$ & $\begin{array}{l}1.91(0.79, \\
4.60)\end{array}$ & $\begin{array}{l}9.50(2.60, \\
34.71)\end{array}$ & $\begin{array}{l}6.71(1.77, \\
25.46)\end{array}$ & $\begin{array}{l}2.11(0.98 \\
4.54)\end{array}$ & $\begin{array}{l}4.33(0.92, \\
20.39)\end{array}$ \\
\hline Moderate & $\begin{array}{l}0.44(0.06 \\
3.01)\end{array}$ & $\begin{array}{l}0.50(0.15 \\
1.65)\end{array}$ & $\begin{array}{l}0.67(0.30 \\
1.47)\end{array}$ & $\begin{array}{l}0.89(0.49, \\
1.62)\end{array}$ & $\begin{array}{l}1.98 \\
(1.08, \\
3.62)\end{array}$ & $\begin{array}{l}2.71 \\
(1.56 \\
4.70)\end{array}$ & $\begin{array}{l}1.18(0.48, \\
2.89)\end{array}$ & $\begin{array}{l}0.76(0.38 \\
1.54)\end{array}$ & $\begin{array}{l}0.99 \text { (0.47, } \\
2.07)\end{array}$ & $\begin{array}{l}1.14(0.47, \\
2.78)\end{array}$ \\
\hline \multicolumn{11}{|c|}{ Country income level } \\
\hline $\begin{array}{l}\text { High-income } \\
\text { (HIC) (Ref) }\end{array}$ & 1.00 & 1.00 & 1.00 & 1.00 & 1.00 & 1.00 & 1.00 & 1.00 & 1.00 & 1.00 \\
\hline $\begin{array}{l}\text { Low/middle- } \\
\text { income (LMIC) }\end{array}$ & $\begin{array}{l}3.87(0.81 \\
18.53)\end{array}$ & $\begin{array}{l}12.17 \\
(3.03,49.00)\end{array}$ & $\begin{array}{l}0.67(0.23 \\
1.94)\end{array}$ & $\begin{array}{l}1.96 \\
(1.02, \\
3.77)\end{array}$ & $\begin{array}{l}1.98 \\
(1.09 \\
3.60)\end{array}$ & $\begin{array}{l}2.16 \\
(1.19 \\
3.94)\end{array}$ & $\begin{array}{l}0.44(0.15 \\
1.31)\end{array}$ & $\begin{array}{l}1.21(0.55 \\
2.65)\end{array}$ & $\begin{array}{l}1.30(0.57 \\
2.97)\end{array}$ & $\begin{array}{l}3.17(0.86, \\
11.75)\end{array}$ \\
\hline \multicolumn{11}{|c|}{ Go outside during COVID-19 } \\
\hline No (Ref) & 1.00 & 1.00 & 1.00 & 1.00 & 1.00 & 1.00 & 1.00 & 1.00 & 1.00 & 1.00 \\
\hline Yes & $\begin{array}{l}1.75 \\
(1.10 \\
2.78)\end{array}$ & $\begin{array}{l}1.70(1.05 \\
2.75)\end{array}$ & $\begin{array}{l}1.70(1.06, \\
2.71)\end{array}$ & $\begin{array}{l}1.52(0.95 \\
2.45)\end{array}$ & $\begin{array}{l}1.20(0.76 \\
1.89)\end{array}$ & $\begin{array}{l}1.19(0.75 \\
1.89)\end{array}$ & $\begin{array}{l}1.53(0.93 \\
2.51)\end{array}$ & $\begin{array}{l}1.51(0.92 \\
2.45)\end{array}$ & $\begin{array}{l}4.21(1.46, \\
12.18)\end{array}$ & $\begin{array}{l}3.30 \\
(1.12, \\
9.76)\end{array}$ \\
\hline \multicolumn{11}{|c|}{ Parent's concern about child's movement behaviour ${ }^{\S}$} \\
\hline No (Ref) & 1.00 & 1.00 & N/A & N/A & 1.00 & 1.00 & 1.00 & 1.00 & N/A & N/A \\
\hline Yes & $\begin{array}{l}0.49 \\
(0.34, \\
0.72)\end{array}$ & $\begin{array}{l}0.50(0.34, \\
0.74)\end{array}$ & & & $\begin{array}{l}0.60 \\
(0.42 \\
0.86)\end{array}$ & $\begin{array}{l}0.68 \\
(0.47 \\
0.96)\end{array}$ & $\begin{array}{l}1.00(0.65 \\
1.56)\end{array}$ & $\begin{array}{l}0.97(0.63 \\
1.50)\end{array}$ & & \\
\hline
\end{tabular}

Parent's perceived ability to support child to have healthy movement behaviours

$\begin{array}{lllllllllll}\text { No (Ref) } & 1.00 & 1.00 & 1.00 & 1.00 & 1.00 & 1.00 & 1.00 & 1.00 & 1.00 & 1.00 \\ \text { Yes } & 1.25(0.77, & 1.15(0.71, & \mathbf{2 . 1 9}(\mathbf{1 . 3 5}, & \mathbf{1 . 8 9} & 1.15(0.74, & 1.14(0.73, & 0.99(0.61, & 0.87(0.54, & 1.56(0.71, & 1.14(0.51, \\ & 2.01) & 1.86) & \mathbf{3 . 5 5}) & \mathbf{( 1 . 1 7}, & 1.79) & 1.79) & 1.59) & 1.41) & 3.45) & 2.51)\end{array}$

Presence of outdoor space within house compound

$\begin{array}{lllllllllll}\text { No (Ref) } & 1.00 & 1.00 & 1.00 & 1.00 & 1.00 & 1.00 & 1.00 & 1.00 & 1.00 & 1.00 \\ \text { Yes } & \mathbf{1 . 8 8} & \mathbf{2 . 4 1}(\mathbf{1 . 3 2}, & \mathbf{2 . 6 1 ( \mathbf { 1 . 5 5 } ,} \mathbf{2 . 6 1} & 1.29(0.81, & 1.14(0.70, & 0.80(0.46, & 0.65(0.38, & \mathbf{2 . 8 3}(\mathbf{1 . 4 3}, & 1.82(0.78, \\ & \mathbf{( 1 . 0 7} & \mathbf{4 . 4 1 )} & \mathbf{4 . 4 0}) & \mathbf{( 1 . 5 6 ,} & 2.06) & 1.87) & 1.38) & 1.11) & \mathbf{5 . 6 0 )} & 4.23)\end{array}$

Number of adults living within the same household

$\begin{array}{lllllllllll}\text { Two or less (Ref) } & 1.00 & 1.00 & 1.00 & 1.00 & 1.00 & 1.00 & 1.00 & 1.00 & 1.00 & 1.00 \\ \text { More than two } & \mathbf{1 . 6 4} & \mathbf{1 . 5 5}(\mathbf{1 . 0 4}, & 0.98(0.68, & 0.97(0.67, & 0.98(0.70, & 0.96(0.68, & 1.04(0.70, & 1.12(0.76, & 0.96(0.54, & 1.06(0.58, \\ & \mathbf{( 1 . 1 2}, & \mathbf{2 . 3 3}) & 1.39) & 1.40) & 1.37) & 1.36) & 1.53) & 1.66) & 1.70) & 1.94)\end{array}$

Number of children living within the same household

$\begin{array}{lllllllllll}\text { Two or less (Ref) } & 1.00 & 1.00 & 1.00 & 1.00 & 1.00 & 1.00 & 1.00 & 1.00 & 1.00 & 1.00 \\ \text { More than two } & 1.21(0.74, & 1.27(0.76, & 1.01(0.66, & 0.92(0.59, & 0.99(0.65, & 0.85(0.56, & 0.99(0.62, & 1.01(0.63, & 1.42(0.76, & 1.22(0.64, \\ & 1.98) & 2.13) & 1.56) & 1.45) & 1.50) & 1.31) & 1.58) & 1.61) & 2.63) & 2.33)\end{array}$

Parent's perceived level of stress compared to before COVID-19

$\begin{array}{lllllllllll}\begin{array}{l}\text { Less/about the } \\ \text { same (Ref) }\end{array} & 1.00 & 1.00 & 1.00 & 1.00 & 1.00 & 1.00 & 1.00 & 1.00 & 1.00 & 1.00 \\ \text { More stressed } & 1.03(0.69, & 1.41(0.87, & 1.04(0.71, & 0.98(0.63, & \mathbf{0 . 6 5} & 0.90(0.59, & 0.86(0.56, & 1.06(0.65, & \mathbf{0 . 5 0}(\mathbf{0 . 2 6 ,} & 0.56(0.26, \\ & 1.53) & 2.28) & 1.52) & 1.54) & \mathbf{( 0 . 4 5 ,} & 1.37) & 1.33) & 1.73) & \mathbf{0 . 9 3}) & 1.18)\end{array}$

Parent's perceived level of exhaustion compared to before COVID-19

$\begin{array}{lllllllllll}\text { Less/about the } & 1.00 & 1.00 & 1.00 & 1.00 & 1.00 & 1.00 & 1.00 & 1.00 & 1.00 & 1.00\end{array}$


Table 4 Logistic regression of associations between meeting WHO Global guidelines and selected COVID-19 factors (Continued)

\begin{tabular}{|c|c|c|c|c|c|c|c|c|c|c|}
\hline & \multicolumn{2}{|c|}{ TPA guideline } & \multicolumn{2}{|c|}{ MVPA guideline } & \multicolumn{2}{|c|}{ SST guideline } & \multicolumn{2}{|c|}{ Sleep guideline } & \multicolumn{2}{|c|}{ All guidelines } \\
\hline & Model 1 & Model 2 & Model 1 & Model 2 & Model 1 & Model 2 & Model 1 & Model 2 & Model 1 & Model 2 \\
\hline \multicolumn{11}{|l|}{ same (Ref) } \\
\hline More exhausted & $\begin{array}{l}0.73(0.50 \\
1.06)\end{array}$ & $\begin{array}{l}0.65(0.41, \\
1.02)\end{array}$ & $\begin{array}{l}1.18(0.82 \\
1.70)\end{array}$ & $\begin{array}{l}1.17(0.75 \\
1.83)\end{array}$ & $\begin{array}{l}0.63 \\
(0.43 \\
0.90)\end{array}$ & $\begin{array}{l}0.74(0.49 \\
1.13)\end{array}$ & $\begin{array}{l}0.62(0.41, \\
0.94)\end{array}$ & $\begin{array}{l}0.59 \text { (0.37, } \\
0.95)\end{array}$ & $\begin{array}{l}0.71(0.39 \\
1.30)\end{array}$ & $\begin{array}{l}1.16(0.57 \\
2.33)\end{array}$ \\
\hline \multicolumn{11}{|c|}{ Receiving any supports from childcare centre } \\
\hline No (Ref) & 1.00 & 1.00 & 1.00 & 1.00 & 1.00 & 1.00 & 1.00 & 1.00 & 1.00 & 1.00 \\
\hline Yes & $\begin{array}{l}1.23(0.63 \\
2.39)\end{array}$ & $\begin{array}{l}1.33(0.67, \\
2.64)\end{array}$ & $\begin{array}{l}1.55(0.85 \\
2.85)\end{array}$ & $\begin{array}{l}1.64 \text { (0.88, } \\
3.09)\end{array}$ & $\begin{array}{l}1.16(0.66, \\
2.05)\end{array}$ & $\begin{array}{l}1.18(0.64, \\
2.16)\end{array}$ & $\begin{array}{l}1.82(0.96 \\
3.46)\end{array}$ & $\begin{array}{l}1.64 \text { (0.87, } \\
3.09)\end{array}$ & $\begin{array}{l}1.76(0.66, \\
4.70)\end{array}$ & $\begin{array}{l}1.47(0.51, \\
4.25)\end{array}$ \\
\hline \multicolumn{11}{|c|}{ Using any resources to support/facilitate child's movement behaviours at home } \\
\hline No (Ref) & 1.00 & 1.00 & 1.00 & 1.00 & 1.00 & 1.00 & 1.00 & 1.00 & 1.00 & 1.00 \\
\hline Yes & $\begin{array}{l}1.12(0.77, \\
1.64)\end{array}$ & $\begin{array}{l}1.16(0.78 \\
1.72)\end{array}$ & $\begin{array}{l}1.39(0.93 \\
2.08)\end{array}$ & $\begin{array}{l}1.40(0.93, \\
2.12)\end{array}$ & $\begin{array}{l}0.89 \text { (0.61, } \\
1.28)\end{array}$ & $\begin{array}{l}0.99(0.68, \\
1.43)\end{array}$ & $\begin{array}{l}1.11(0.67 \\
1.82)\end{array}$ & $\begin{array}{l}1.05(0.65 \\
1.71)\end{array}$ & $\begin{array}{l}0.98(0.54 \\
1.77)\end{array}$ & $\begin{array}{l}1.15(0.63, \\
2.09)\end{array}$ \\
\hline
\end{tabular}

TPA total physical activity, MVPA moderate-to-vigorous intensity physical activity, SST sedentary screen time

Data are presented as odds ratios ( $95 \%$ confidence interval); bold value indicates statistically significant effect

Model 1: Adjusted for age (at T2) by sex interaction, rurality, childcare centre (as random effects), country sites (as random effects), parents' highest level of education, children who reported as sick at T2 (preventing from being active at T2), and corresponding T1 measures (e.g., meeting/not meeting TPA guideline at T1 for TPA model)

Model 2: Similar to Model 1 but also included other COVID-19 factors

${ }^{\S}$ Separate questions were asked for total physical activity, sitting (including screen time) and sleep, but not for MVPA

around bedtime, with parents allowing their child to go to bed slightly later. These patterns are consistent with what is observed during holiday periods and on weekends [22].

Children spent less time outdoors on weekdays and weekend days during the pandemic. This is consistent with other studies of children and youth during the pandemic $[12,18]$. Time spent outdoors provides many benefits for children and their parents including higher levels of PA [23]; indeed, in those countries where children were able to play outdoors, higher levels of PA were reported. Policies that allow children to play outdoors while at the same time minimising the risk of transmission of infection are needed. Wearing masks and enforcing physical distancing in playgrounds, parks and other green spaces may provide a solution to this challenge.

Our results highlight the important role parents play in supporting their child to participate in healthy levels of movement behaviours. Parents of children who were less likely to meet SST or PA guidelines, were more concerned about their children's movement behaviours than parents whose children met the guidelines. This highlights that even though parents were aware that these behaviours were being compromised because of COVID-19, and were concerned by this, they were not necessarily in a position to address their concerns. This may be due to work/time constraints or parental stress and exhaustion. These parents' concerns may have been further perpetuated if they were spending more time at home with their children than usual and so were acutely aware of their children's movement behaviours.
However, children whose parents believed they had the ability to support their child were more likely to meet the MVPA guidelines compared with those who did not believe this. It is plausible that these parents were already actively encouraging their children to increase movement, thus reporting a significant amount of time spent in MVPA [12, 24]. This distinction between the influence of parents' reported concern (their belief), versus their ability to support their child's movement behaviours (their behaviour), raises questions regarding how best to support parents to encourage children's movement behaviours during times of increased stress and exhaustion such as during COVID-19. This association between parent concern and children's movement behaviours is encouraging because it shows that parents are aware of the importance of healthy levels of these behaviours at this age and of the need to support their child in meeting guidelines.

One-third of parents reported feeling more stressed and exhausted during COVID-19, compared with the period prior to the pandemic. High levels of parental stress and exhaustion were related to poorer movement behaviour outcomes. This is not surprising with ECEC services closed in many countries and parents juggling working from home and educating their children during this period. An association between the struggle to handle childcare responsibilities during COVID-19 and heightened levels of stress and exhaustion within the home environment [25]. Combined with not being able to go outside as normal or children not able to play with their friends creates a "perfect storm" for higher levels of 
parental stress and exhaustion. It is possible that parent exhaustion, and children's change in sleep, could be attributed to any number of heightened stressors during the pandemic, with family downtime and typical routines thrown out of balance. For instance, engagement with social media and other communication technologies during the pandemic may result in undue stress and anxiety for both parents and children, with potential lasting impacts on daily routines [20].

Children in LMICs were more likely to meet movement behaviour guidelines then those in HICs. All countries with high levels of restrictions were LMICs. Higher levels of restriction were associated with lower movement behaviours, but living in an LMIC was associated with a higher likelihood of meeting PA and SST guidelines. This was due to children in some LMICs leaving the cities to spend time with relatives in rural areas, particularly during school holidays, where they had more access to outdoor spaces and enforcement of COVID restrictions were not as strict. With less restriction on their ability to go outside, these children were likely to be adequately active and less engaged in screen time.

Children living in countries with low or moderate restrictions were more likely to meet the guidelines for all three movement behaviours, compared with children living in countries with high levels of restrictions. These finding suggest that there is an interrelationships among the movement behaviours and that COVID restrictions can have an impact on children across the entire day. Not being able to go outside greatly reduces the opportunities children have for PA, and consequently children's engagement in SST increases. Lower levels of PA and higher levels of SST in these children results in shorter total sleep durations.

\section{Generalisability}

We found that when examining all the countries collectively there were no significant differences in the proportion of children who met all four movement behaviour guidelines during COVID compared to before the pandemic. Of the individual guidelines, only SST increased during the pandemic. As convenience sampling was used, these results are not generalisable beyond the study participants.

\section{Limitations}

A limitation of the study was that movement behaviours were captured via parent report and not objectively measured. While the coefficients obtained from the concurrent validity of the PA questions against accelerometry were low, they are typical for what one might see for a PA question vs accelerometry [26]. Although 72-h accelerometry data for Time 1 was available for comparison, given the range of severity of the pandemic restrictions in participating countries, it was determined by the authors that it would not be feasible to collect accelerometer data across all settings at the height of the pandemic (T2). There is a possibility that parents may have under-reported children's PA levels before COVID19 , as they may not have been aware of the extent of their child's PA in the ECEC setting as well as due to limited time spent with their children.

At both time-points parent completed the survey via interview in the majority of cases $(54.5 \%$ at $\mathrm{T} 1$ and $90.7 \%$ at T2). While in many countries, the same research teams collected data at $\mathrm{T} 1$ and $\mathrm{T} 2$ and no differences in participants' willingness to answer the survey was reported during data collection, there may have been some degree of social desirability response bias in the parent reporting of their child's movement behaviours before and during COVID. This may be particularly evident among parents who completed the survey via interview. However, since parents were not informed of the WHO Global guidelines prior to reporting their child's movement behaviours, they may not have felt the need to report against ideal levels of movement behaviours, thereby reducing the likelihood of social desirability bias [27]. While the overall sample size was close to 1000 , it was small in a number of countries and the children who participated are not necessarily representative of a broader population.

\section{Implications for future research, policy and practice}

- The strength of the associations between levels of government restrictions and all three movement behaviours highlights that priority must be given to keeping ECEC services open if it is feasible to do so in a COVID-safe manner. This will support children to accrue the recommended movement behaviours.

- Being allowed outside during times of movement restrictions was independently associated with meeting all guidelines, emphasising the importance of i) allowing people to go outside each day, ii) parents providing opportunities for children to be outside, and iii) promoting active play for children when outside, with appropriate risk-mitigation strategies.

- The findings highlight the importance of access to public green spaces, particularly in densely populated urban areas and for those without a garden/yard attached to their home. This has implications for land use policy, urban planning and housing design and development (e.g. rooftop gardens).

- Having parents and children spending more time at home during times of movement restrictions, provides opportunities for parents to participate in 
physical activity together with their child. This could potentially result in improved mental health outcomes and increased PA for parents, coupled with increased PA and reduced SST for children [28, 29]. It would also encourage social interaction and enjoyment among children and their parents.

- Developing resources that provide suggestions for ways to incorporate both indoor and outdoor physical activity, reduce SST and facilitate heathy levels of sleep, during times of movement restrictions could be particularly beneficial for both parents and children

- Outdoor activities could include a nature walk or time spent at the playground, in the park/field playing tag, ball games or imaginative free play.

- Indoor activities that do not require a lot of equipment and can keep children entertained for a considerable time include building a playhouse using blankets, boxes or towels, soft balls, playing hide and seek, or dancing to music.

- Adapting equipment for small indoor spaces could include using a balloon instead of a ball, or using a skipping rope instead of running, or household items such as rolled up socks and a basket.

- Co-viewing and interacting with children during SST and selecting educational content and active engagement over passive viewing is recommended [21].

- Try to maintain regular bed and wake times. Be mindful that going to bed later (and waking up later), while still resulting in the same sleep duration may not be as beneficial as going to bed earlier (and waking up earlier). Keeping children active during the day, will also ensure they are tired and able to keep to regular sleep times.

- Parental mental health needs to be considered when deciding what level of restrictions to impose to control the spread of COVID-19 and the consequences such restrictions may have on other aspects of health. In countries where levels of restrictions were low, parents' stress and exhaustion were not as high, reaffirming that such restrictions impact parents, which may subsequently impact the child. Policymakers need to consider this in future pandemics or in subsequent waves of COVID-19 when making decisions about whether to close ECEC services or to adopt strict home quarantine orders.

- The aggregated data across the 14 countries suggested that there was not a considerable change in the children's overall levels of PA (TPA and MVPA) from before to during the COVID-19 pandemic. Further research is required to explore differences in PA at the individual country level, to determine how the associated factors vary across different contexts and levels of restrictions and what the implications of this are.

\section{Conclusion}

This study is unique as it reports on longitudinal changes in movement behaviour in a diverse, international population of young children from urban and rural locations, and the influence of movement restriction imposed by governments in response to the COVID-19 pandemic. Eight of the countries and 71\% of participants are low- or middle-income; we know very little about movement behaviours or the impact of COVID-19 in these countries. This study presents a magnitude of changes in movement behaviours, adding to existing findings reporting parents' perceptions of changes in movement behaviours during the pandemic.

With PA and SST levels of children from LMICs less impacted by COVID-19 than HICs, the results highlight that factors, which influence healthy levels of movement behaviours, differ between HICs and LMICs and consequently the implications vary. Policies and efforts therefore need to be specific to each country's context. We suggest that future international studies present results that disaggregated by regions or income levels to best capture this variability.

Children in disadvantaged communities who do not have access to an outdoor space could be particularly affected as these areas become critically important during periods when restrictions are enforced. These findings can inform efforts to support parents of young children to promote a healthy balanced pattern of movement behaviours during the COVID-19 outbreak, the recovery phase and future pandemics. Parents' stress and exhaustion levels and their self-efficacy to support healthy movement behaviour patterns in their children needs to be addressed.

\section{Supplementary Information}

The online version contains supplementary material available at https://doi. org/10.1186/s12889-021-10852-3.

Additional file 1: Table S1: Parent/Caregiver Survey. Table S2

Descriptive characteristics of participating countries. Table S3.

Characteristics of analytic sample. Table S4. Distribution of analytic

sample according to COVID-19 factors

\footnotetext{
Acknowledgements

We would like to thank all the parents, children, Early Childhood Education Care service staff, and data collectors who participated in this study. We thank the SUNRISE Leadership Group members for their contribution to the conceptualisation and support for the implementation of the SUNRISE pilot study. We would like to thank the following individuals for their contribution: Chi L.D. Nguyen; Ellinor Nilsson; Imane El Menchawy; Iztiba Mallik Deeba; Jajat; K.A.D Kumari; Johan Ng; M.P.K Gayamini; Maria Henström; Mahmudul Hasan; Mesa Rahmi Stephani; Nhan M. Le; Nur Indri Rahayu; Syifa F. Syihab; Serina Wehbe El Masri; Risma; Wulandari Putri.
} 


\section{Authors' contributions}

A D O is responsible for the overall content as guarantor. A D O, KE K, E KT contributed to the literature search, study design, data analysis, data interpretation, writing and review of the manuscript. G H, TS, P L C, K H C, R C contributed to the study design, data collection, data analysis, data interpretation, writing and review of the manuscript. CE D, contributed to the study design, data interpretation and review of the manuscript. A S, A T, A E S, A S H, A E H, A B, B K P, B D P C, C H S C, C D N, D K, E. KW, H L, HK. $T$, I B, J D P C, J E W, KS, M N, M L, MM C, M S H, P W P C, S F, T V. K, U K, V $\mathrm{PW}$ and $\mathrm{XW}$ contributed to data collection, data interpretation and review of the manuscript. The authors read and approved the final manuscript.

\section{Funding}

This study was supported by a NHMRC Investigator Grant awarded to the first author.

\section{Availability of data and materials}

The data that support the findings of this study are available from participating country contacts but restrictions apply to the availability of these data, which were used under license for the current study, and so are not publicly available. Data are however available from the authors upon reasonable request and with permission of all participating country contacts and the relevant ethics committees.

\section{Declarations}

\section{Ethics approval and consent to participate}

The research was performed in accordance with the Declaration of Helsinki. Overall research approval for the study was obtained from the Human Research Ethics Committee (Ref: 2018/044) from the University of Wollongong, Australia. Each wave of data collection was approved by the relevant Human Research Ethics Committees in each participating country.

\section{Consent for publication}

Informed consent for publication has been obtained from all participants.

\section{Competing interests}

The authors have no financial or non-financial competing interests to declare.

\section{Author details}

'Early Start, School of Health and Society, Faculty of the Arts, Social Science and Humanities, University of Wollongong, Wollongong, NSW 2522, Australia. ${ }^{2}$ Department of Early Childhood Development, Beijing Municipal Key Laboratory of Child Development and Nutriomics, Capital Institute of Pediatrics, Beijing, China. ${ }^{3}$ Early Start, Faculty of the Arts, Social Science and Humanities, University of Wollongong, Wollongong, NSW 2522, Australia. ${ }^{4}$ NIASRA - National Institute for Applied Statistics Research Australia, School of Mathematics and Applied Statistics, Faculty of Engineering and Information Sciences, University of Wollongong, Wollongong, NSW 2522 Australia. ${ }^{5}$ Faculty of Sport and Health Education, Universitas Pendidikan Indonesia, Bandung, Jawa Barat, Indonesia. ${ }^{6}$ Precision Health Consultants (PHC Global), Karachi, Pakistan. ${ }^{7}$ Pennington Biomedical Research Center, 6400 Perkins Rd Baton Rouge Louisiana, Pennington 70808, USA. ${ }^{8}$ Department of Sports Science and Physical Education, Faculty of Education, The Chinese University of Hong Kong, Hong Kong, China. ${ }^{9}$ Unité Mixte de Recherche Nutrition et Alimentation, CNESTEN - Université Ibn Tofail (URAC-39), Regional Designated Center of Nutrition Associated with AFRA/ IAEA, Pennington, USA. ${ }^{10}$ Centre for Community Health Studies (ReaCH), Faculty of Health Sciences, Universiti Kebangsaan Malaysia, 50300 Kuala Lumpur, Malaysia. "1Department of Sports Science and Clinical Biomechanics, Centre for Active and Healthy Ageing, University of Southern Denmark, Odense, Denmark. ${ }^{12}$ Department of Biosciences and Nutrition, Karolinska Institutet, 14183 Huddinge, Sweden. ${ }^{13}$ Centre of Community Education and Well-being, Faculty of Education, Universiti Kebangsaan Malaysia, 43600 UKM Bangi, Malaysia. ${ }^{14}$ Institute of Public and Preventive Health, Augusta University, 1120 15th Street, Augusta, GA 30912, USA. ${ }^{15}$ Vadu Rural Health Program, KEM Hospital Research Centre, Rasta Peth, Pune, India. ${ }^{16}$ Department of Epidemiology, Faculty of Public Health, Pham Ngoc Thach University of Medicine, Ho Chi Minh City, Vietnam. ${ }^{17}$ Departamento de Educación Física y Deporte, Universidad de Sevilla, Sevilla, Spain.
${ }^{18}$ Department of Health, Medicine and Caring Sciences, Linköping University, 58183 Linköping, Sweden. ${ }^{19}$ Biomedical Research Foundation, Dhaka, Bangladesh. ${ }^{20}$ Department of Paediatrics, Faculty of Medicine, University of Colombo, Colombo, Sri Lanka. ${ }^{21}$ SAMRC/Wits Developmental Pathways for Health Research Unit, University of the Witwatersrand, Witwatersrand, South Africa.

Received: 20 November 2020 Accepted: 9 April 2021

Published online: 17 May 2021

\section{References}

1. Douglas M, Katikireddi SV, Taulbut M, McKee M, McCartney G. Mitigating the wider health effects of covid-19 pandemic response. BMJ. 2020;369(April):16. doi:https://doi.org/10.1136/bmj.m1557.

2. WHO. WHO Guidelines on Physical Activity, Sedentary Behaviour for Children under 5 Years of Age.; 2019. https://apps.who.int/iris/bitstream/ha ndle/10665/325147/WHO-NMH-PND-2019.4-eng.pdf? sequence=1\&isA llowed=y\%0Ahttp://www.who.int/iris/handle/10665/31 1664\%0Ahttps://apps. who.int/iris/handle/10665/325147

3. Okely AD, Tremblay MS, Reilly JJ, Draper CE, Bull F. Physical activity, sedentary behaviour, and sleep: movement behaviours in early life. Lancet Child Adolesc Heal. Published online 2018. doi: https://doi.org/10.1016/S23 52-4642(18)30070-1.

4. Saunders TJ, Gray CE, Poitras VJ, Chaput JP, Janssen I, Katzmarzyk PT, et al. Combinations of physical activity, sedentary behaviour and sleep: relationships with health indicators in school-aged children and youth. Appl Physiol Nutr Metab. 2016;41(6):S283-93. https://doi.org/10.1139/apnm-2015-0626.

5. Kuzik N, Poitras VJ, Tremblay MS, Lee EY, Hunter S, Carson V. Systematic review of the relationships between combinations of movement behaviours and health indicators in the early years (0-4 years). BMC Public Health. 2017; 17(Suppl 5). https://doi.org/10.1186/s12889-017-4851-1.

6. Biddle SJH, Ciaccioni S, Thomas G, Vergeer I. Physical activity and mental health in children and adolescents: an updated review of reviews and an analysis of causality. Psychol Sport Exerc. 2019;42:146-55. https://doi.org/1 0.1016/j.psychsport.2018.08.011

7. Langford R, Bonell CP, Jones HE, Pouliou T, Murphy SM, Waters E, et al. Health promoting school framework for improving the health and wellbeing of students and their academic achievement. Cochrane Database Syst Rev. 2014:4:CD008958.

8. Guan H, Okely AD, Aguilar-Farias N, Cruz Del P, Eha A, et al. Promoting healthy movement behaviours among children during the COVID-19 pandemic. Lancet Child Adolesc Heal. 2020;4642(20):19-20. https://doi.org/1 $0.1016 / 52352-4642(20) 30131-0$

9. The World Bank. World Bank Country and Lending Groups. https://data helpdesk.worldbank.org/knowledgebase/articles/906519

10. Harris PA, Taylor R, Thielke R, Payne J, Gonzalez N, Conde JG. Research electronic data capture (REDCap) - a metadata-driven methodology and workflow process for providing translational research informatics support. $J$ Biomed Inf. 2009;42(2):377-81. https://doi.org/10.1016/j.jbi.2008.08.010.Research.

11. Okely AD, Ghersi D, Hesketh KD, et al. A collaborative approach to adopting/adapting guidelines - The Australian 24-Hour Movement Guidelines for the early years (Birth to 5 years): An integration of physical activity, sedentary behavior, and sleep. BMC Public Health. 2017;17(Suppl 5). https://doi.org/10.1186/s12889-017-4867-6.

12. Moore $\mathrm{S}$, Faulkner $\mathrm{G}$, Rhodes $\mathrm{R}$, et al. Impact of the COVID-19 virus outbreak on movement and play behaviours of Canadian children and youth: a national survey. Submitted. Published online 2020: 1-23. doi:10.21203.

13. Thomas H, Angrist N, Cameron-Blake E, et al. Oxford COVID-19 government response tracker, Blavatnik School of Government. Published 2020. https:// covidtracker.bsg.ox.ac.uk/

14. Cliff DP, McNeill J, Vella S, Howard SJ, Kelly MA, Angus DJ, et al. The preschool activity, technology, health, adiposity, behaviour and cognition (PATH-ABC) cohort study: rationale and design. BMC Pediatr. 2017;17(1):1-9. https://doi.org/10.1186/s12887-017-0846-4.

15. Barber SE, Kelly B, Collings PJ, Nagy L, Bywater T, Wright J. Prevalence, trajectories, and determinants of television viewing time in an ethnically diverse sample of young children from the UK. Int I Behav Nutr Phys Act. 2017;14(1):1-11. https://doi.org/10.1186/s12966-017-0541-8.

16. R Core Team. The R Project for Statistical Computing. R Foundation for Statistical Computing. Vienna. Accessed July 14, 2020. https://www.r-project.org/ 
17. Bates D, Mächler M, Bolker BM, Walker SC. Fitting linear mixed-effects models using Ime4. J Stat Softw. 2015;67(1). https://doi.org/10.18637/jss.V067.01.

18. Dunton GF, Do B, Wang SD. Early effects of the COVID-19 pandemic on physical activity and sedentary behavior in children living in the U.S. BMC Public Health. 2020;20(1):1351. https://doi.org/10.1186/s12889-020-09429-3.

19. Pombo A, Luz C, Rodrigues LP, Ferreira C, Cordovil R. Correlates of Children's Physical Activity During the Covid-19 Confinement in Portugal. Public Health. Published online 2020. doi:https://doi.org/10.1016/j.puhe.2020.09.009

20. Drouin M, McDaniel BT, Pater J, Toscos T. How Parents and Their Children Used Social Media and Technology at the Beginning of the COVID-19 Pandemic and Associations with Anxiety. Cyberpsychol Behav Soc Netw. 2020. https://doi.org/10.1089/cyber.2020.0284.

21. Hill D, Ameenuddin N, Chassiakos YR, et al. Media and young minds. Pediatrics. 2016;138(5). https://doi.org/10.1542/peds.2016-2591.

22. Armstrong B, Beets MW, Starrett A, et al. Dynamics of sleep, sedentary behavior, and moderate-to-vigorous physical activity on school versus nonschool days. Sleep. 2020;(September): 1-12. doi:https://doi.org/10.1093/ sleep/zsaa174

23. Bento G, Dias $G$. The importance of outdoor play for young children's healthy development. Porto Biomed J. 2017;2(5):157-60. https://doi.org/10.1 016/j.pbj.2017.03.003.

24. Rhodes RE, Stearns J, Berry T, Faulkner G, Latimer-Cheung AE, O'Reilly N Tremblay MS, Vanderloo L, Spence JC Predicting parental support and parental perceptions of child and youth movement behaviors. Psycho Sport Exerc 2019;41(November 2018):80-90. doi:https://doi.org/10.1016/j. psychsport.2018.11.016.

25. Griffith AK. Parental Burnout and Child Maltreatment During the COVID-19 Pandemic. J Fam Violence. Published online 2020. doi:https://doi.org/10.1 007/s10896-020-00172-2

26. Sarker $\mathrm{H}$, Anderson LN, Borkhoff CM, et al. Validation of parent-reported physical activity and sedentary time by accelerometry in young children pediatrics. BMC Res Notes. 2015;8(1):1-8. https://doi.org/10.1186/s13104-01 5-1648-0.

27. King MF, Bruner GC. Social desirability bias: a neglected aspect of validity testing. Psychol Mark. 2000;17(2):79-103. https://doi.org/10.1002/(SICl)15206793(200002) 17:2<79:AID-MAR2>3.0.CO;2-0.

28. Dunton GF, Liao Y, Almanza E, et al. Joint physical activity and sedentary behavior in parent-child pairs. Med Sci Sport Exerc. 2012;44(8):1473-80. https://doi.org/10.1249/MSS.0b013e31825148e9.

29. Fuemmeler BF, Anderson CB, Mâsse LC. Parent-child relationship of directly measured physical activity. Int J Behav Nutr Phys Act. 2011;8(1):1-9. https:// doi.org/10.1186/1479-5868-8-17.

\section{Publisher's Note}

Springer Nature remains neutral with regard to jurisdictional claims in published maps and institutional affiliations.

Ready to submit your research? Choose BMC and benefit from:

- fast, convenient online submission

- thorough peer review by experienced researchers in your field

- rapid publication on acceptance

- support for research data, including large and complex data types

- gold Open Access which fosters wider collaboration and increased citations

- maximum visibility for your research: over $100 \mathrm{M}$ website views per year

At $\mathrm{BMC}$, research is always in progress.

Learn more biomedcentral.com/submissions 